\title{
Kajian Semiotika Lagu Kebangsaan Afrika Selatan Nkosi Sikelel 'iAfrika
}

\author{
Michelle Gabriela, Suzy Azeharie \\ mchellegbriela14@gmail.com,suzya@fikom.untar.ac.id
}

Fakultas Ilmu Komunikasi Universitas Tarumanagara

\begin{abstract}
This study is titled the Study of Semiotics of the National Anthem of South Africa Nkosi Sikelel 'iAfrika. The research objective was to determine the study of semiotics in the African national anthem (Nkosi Sikelel el iAfrika). The song consists of five official languages in South Africa while those on other national anthems are only written in one language. The author chose this South African national anthem because there are religious, social and political values in it. This study uses the semiotic method, which is a method that analyzes the sign. The study will use observations on songs, in-depth interviews with the staff of the Political and Cultural Section of the South African Embassy in Jakarta. The research data was obtained from observation, interviews, literature studies and online data. The theory used in the study is semiotic analysis of Ferdinand de Saussure. The conclusion of this study is that the South African national anthem contains the concept of divinity because religion is important for the people of South Africa and the majority of the population is Christian. Then this song contains historical value, especially the struggle of black people during Apartheid's political period. Furthermore this song also contains the philosophy of 'Ubuntu' which is applied in the community life in South Africa.
\end{abstract}

Keywords: Semiotics, Ferdinand de Saussure, National Anthem, South Africa, Nkosi Sikelel iAfrika

\begin{abstract}
Abstrak
Penelitian ini mengkaji semiotika Lagu Kebangsaan Afrika Selatan Nkosi Sikelel 'iAfrika. Tujuan penelitian ini adalah untuk mengetahui kajian Semiotika dalam lagu kebangsaan Afrika, Nkosi Sikelel 'iAfrika. Lagu ini terdiri dari lima bahasa resmi di Afrika Selatan, sedangkan pada lagu kebangsaan negara lain hanya ditulis dalam satu bahasa. Penulis memilih lagu kebangsaan Afrika Selatan ini karena di dalamnya terdapat nilai agama, sosial dan politik. Penelitian ini menggunakan metode semiotika yaitu metode yang menganalisis tentang tanda. Penelitian akan menggunakan observasi pada lagu, wawancara mendalam dengan staff bagian Politik dan Budaya Kedutaan Besar Afrika Selatan di Jakarta. Data penelitian diperoleh dari observasi, wawancara, studi pustaka dan data online. Teori yang digunakan dalam penelitian adalah analisis semiotika dari Ferdinand de Saussure. Kesimpulan dari penelitian ini adalah lagu kebangsaan Afrika Selatan mengandung konsep ketuhanan karena agama penting bagi masyarakat Afrika Selatan dan mayoritas penduduknya beragama Kristen. Kemudian lagu ini mengandung nilai sejarah khususnya perjuangan rakyat kulit hitam saat masa politik Apartheid. Selanjutnya lagu ini juga mengandung filosofi 'Ubuntu' yang diterapkan dalam kehidupan bermasyarakat di Afrika Selatan.
\end{abstract}

Kata Kunci: Semiotika, Ferdinand de Saussure, Lagu Kebangsaan, Afrika Selatan, Nkosi Sikelel 'iAfrika 


\section{Pendahuluan}

Perbedaan dan keanekaragaman adalah sesuatu yang alamiah. Aang Ridwan dalam bukunya yang berjudul Komunikasi Antarbudaya menegaskan hal ini dengan mengatakan bahwa setiap orang, setiap bangsa memiliki keunikannya sendiri-sendiri. Walaupun batas-batas negara semakin pudar karena kemajuan teknologi akan tetapi perbedaan dan keanekaragaman akan tetap ada (Ridwan, 2016:176).

Ragam kebudayaan menurut Dedi Kurnia Syah dalam bukunya yang berjudul Komunikasi Lintas Budaya merupakan nilai berharga bagi sebuah bangsa. Untuk merajut ragam budaya dapat dimulai dari pandangan tentang ragam kehidupan, kebijakan kebudayaan yang menekankan tentang penerimaan terhadap adanya keragaman budaya yang ada dalam kehidupan masyarakat, menyangkut nilai-nilai, sistem, budaya, kebiasaan, dan politik yang mereka anut (Syah, 2016:39).

Ketika dihadapkan dengan lagu kebangsaan negara asalnya, menurut Avi Gilboa dan Ehud Bodner orang bereaksi dengan perasaan bangga dan patriotisme serta lagu kebangsaan memiliki kekuatan untuk menyatukan orang-orang di sekitar asosiasi yang sama (Gilboa dan Bodner, 2009:1)

Afrika Selatan menurut Paharizal dalam bukunya yang berjudul Long Walk Nelson Mandela merupakan salah satu negara yang menjadi sasaran imperialis dan kolonialis karena negara ini memiliki sumber daya alam yang melimpah, struktur tanah yang subur dan memiliki hasil tambang emas terbesar setelah Indonesia, Nevada, Peru dan Argentina. Hal tersebut menjadi daya tarik bagi bangsa Eropa seperti Portugis dan Belanda untuk melakukan ekspansi hingga ke wilayah tersebut. Mereka dikenal sebagai Afrikaner dan tiba pada tahun 1652. Ketika ditemukan cadangan berlian yang melimpah, Inggris melakukan ekspansi ke wilayah tersebut. Hal tersebut menyebabkan perang Boer antara Inggris dan Belanda tahun 1899-1902 (Paharizal, 2013:3).

Sistem politik apartheid terjadi di Afrika Selatan sekitar awal abad ke-20 hingga tahun 1992. Apartheid diartikan sebagai sebuah sistem pemisahan antar ras yang dilegalkan secara hukum oleh pemerintah. Politik apartheid muncul dan menjadi konstruksi sosial politik melalui rangkaian peristiwa sejarah yang panjang. Mulai dari penjajahan hingga terbentuknya Afrika Selatan sebagai sebuah negara yang diperintah oleh masyarakat yang berasal dari kelompok kulit putih. Selama masa pemerintahan kulit putih, masyarakat kulit hitam dikondisikan dalam situasi yang tidak beradab. Mereka tidak dapat mengakses pendidikan, ekonomi, politik dan secara status sosial dianggap sebagai kelas kedua yang tidak diperhitungkan keberadaannya (Paharizal, 2013:6).

Sejarah menurut Larry A. Samovar, Richard E. Porter dan Edwin R. McDaniel berhubungan dengan asal suatu budaya. Versi singkat Nkosi Sikelel 'iAfrika dan The Call of South Africa resmi menjadi lagu kebangsaan Afrika Selatan dalam Undangundang Afrika Selatan bagian empat tahun 1996 dan proklamasi nomor 68 dalam lembaran pemerintah nomor 18341. Lagu kebangsaan Afrika Selatan tersebut berbeda dari lagu kebangsaan negara lain karena ditulis dalam lima bahasa dari 12 bahasa resmi republik Afrika Selatan. Sementara banyak lagu kebangsaan negara lain ditulis dalam satu bahasa. Dua baris pertama dalam bait pertama Nkosi Sikelel 'iAfrika menggunakan bahasa Xhosa. Dua baris kedua dalam bait pertama menggunakan bahasa Zulu. Bait kedua menggunakan bahasa Sesotho. Bait ketiga menggunakan bahasa Afrikaans (Belanda). Bait terakhir menggunakan bahasa Inggris (Magangane, 2016:1). 
Penulis melakukan penelitian mengenai studi semiotika lagu kebangsaan Afrika Selatan Nkosi Sikelel 'iAfrika karena ingin mengkaji lebih dalam makna dari lagu kebangsaan Afrika Selatan. Penulis tertarik dengan kisah sejarah di balik lagu kebangsaan tersebut. Nkosi Sikelel 'iAfrika merupakan sebuah lagu kebangsaan yang unik karena terdiri dari lima bahasa resmi di Afrika Selatan yaitu bahasa Xhosa, bahasa Zulu, bahasa Sesotho, bahasa Afrikaans dan bahasa Inggris. Penelitian ini menggunakan teori semiotika Ferdinand de Saussure karena teori tersebut mengatakan bahwa bahasa adalah suatu sistem tanda. Melalui teori semiotika Ferdinand de Saussure, penulis mengupas makna di balik keragaman bahasa dalam lagu kebangsaan Afrika Selatan Nkosi Sikelel 'iAfrika.

\section{Metode Penelitian}

Penelitian yang dilakukan penulis bertujuan untuk mengetahui kajian semiotika lagu kebangsaan Afrika Selatan Nkosi Sikelel 'iAfrika. Pada penelitian ini penulis menggunakan metode penelitian kualitatif. Menurut Strauss dan Corbin, penelitian kualitatif adalah jenis penelitian yang menghasilkan penemuan-penemuan yang tidak dapat dicapai dengan menggunakan prosedur-prosedur statistik atau cara-cara lain dari kuantifikasi. Penelitian kualitatif secara umum dapat digunakan untuk penelitian tentang kehidupan masyarakat, sejarah, tingkah laku, fungsionalisasi organisasi, aktivitas sosial (Sujarweni, 2014:19). Sementara menurut Robert C. Bogdan dan Steven J. Taylor, metodologi kualitatif merupakan prosedur penelitian yang menghasilkan data deskriptif berupa kata-kata tertulis atau lisan dari orang-orang dan perilaku yang dapat diamati (Moleong, 2012:4). Penulis menggunakan metode tersebut karena sejalan dengan perumusan masalah penulis yaitu untuk mengetahui kajian semiotika lagu kebangsaan Afrika Selatan Nkosi Sikelel 'iAfrika.

Penelitian ini menggunakan metode semiotika yaitu metode yang menganalisis tentang tanda. Metode semiotika yang akan digunakan dalam penelitian ini adalah semiotika dari pemikiran Saussure. Saussure meletakkan tanda dalam konteks komunikasi manusia dengan melakukan pemilahan antara apa yang disebut signifier (penanda) dan signified (petanda). Eksistensi semiotika Saussure adalah relasi antara penanda dan petanda berdasarkan konvensi sosial, biasa disebut dengan signifikasi. Semiotika signifikasi adalah sistem tanda yang mempelajari relasi elemen tanda dalam sebuah sistem berdasarkan aturan atau konvensi tertentu. Konvensi sosial merupakan kesepakatan sosial yang diperlukan untuk dapat memaknai tanda tersebut (Sobur, 2013:46).

Objek penelitian adalah lagu kebangsaan Afrika Selatan "Nkosi Sikelel 'iAfrika”. Penulis menggunakan studi pustaka yaitu memanfaatkan literatur-literatur, majalah dan buku untuk semakin memperkuat data penelitian. Unit analisis yang digunakan berupa lirik lagu dan audio lagu "Nkosi Sikelel 'iAfrika". Data yang diperlukan penulis diperoleh berdasarkan metode pengumpulan data melalui observasi pada lagu, wawancara mendalam dengan Inayet Hassan (Sekretaris Utama Bagian Politik dan Budaya Kedutaan Besar Afrika Selatan di Jakarta), studi pustaka dan data online. 


\section{Hasil Temuan dan Diskusi}

\section{Aspek Penanda (Signifier)}

Tuhan memberkati Afrika,

Semoga kejayaannya terangkat tinggi.

\section{Aspek Petanda (Signified)}

Sekitar $80 \%$ orang Afrika Selatan beragama Kristen, $15 \%$ tidak berafiliasi dengan agama dan 5\% beragama Islam, Hindu, Yahudi atau agama lain. Kebebasan beragama dijamin oleh konstitusi (https://www.gov.za/about-sa/south-africas-people diakses pada tanggal 25 Juni 2019 pukul 20.25 WIB).

Selanjutnya Inayet Hassan menambahkan bahwa Konsep Ketuhanan sangat penting bagi masyarakat Afrika Selatan pada saat lagu tersebut diciptakan. Tetapi seiring perkembangan jaman terjadi pergeseran nilai keagamaan. Negara Afrika Selatan tidak mengharuskan warganya untuk memeluk suatu agama tertentu. Melainkan membebaskan warganya untuk menganut agama apapun dan berharap dapat hidup rukun walaupun terdapat beragam agama dan kepercayaan. Akan tetapi lagu kebangsaan ini harus dihormati oleh seluruh warga Negara Afrika Selatan. Lagu ini juga dapat disamakan dengan lagu kebangsaan negara lain seperti "God Save the Queen" dan "God Defend New Zealand" yang mengandung kata 'Tuhan' dalam liriknya (wawancara dengan Inayet Hassan di Kedutaan Besar Afrika Selatan, Jakarta pada tanggal 11 Juni 2019 pada pukul 15.10 WIB).

\section{Aspek Penanda (Signifier)}

Dengarkan permohonan kami,

Tuhan memberkati kami, anak-anakmu.

\section{Aspek Petanda (Signified)}

Pada bagian kedua lagu ini masih diambil dari lagu awal 'Nkosi Sikelel 'iAfrika" dari tahun 1925 yang merupakan himne Gereja dan lagu perjuangan rakyat kulit hitam dalam melawan Apartheid. Oleh sebab itu, bagian ini masih menggambarkan keinginan penduduk Afrika Selatan kepada Tuhan untuk mendengarkan permohonan dan doa mereka. Terdapat kata "anak-anakmu" yang menggambarkan penduduk Afrika Selatan menganggap dirinya sebagai seorang anak yang menghormati 'orang tua'. Sosok orang tua di sini adalah Tuhan yang dapat diminta pertolongan dan berkat.

Adrianus Sunarko dalam bukunya yang berjudul Allah Tritunggal Adalah Kasih mengatakan bahwa kekristenan menganut sistem Trilogi atau Allah Tritunggal. Konsep ini menggambarkan suatu kesatuan yang absolut. Allah merupakan satu makhluk yang memiliki tiga pribadi yaitu Allah sebagai Bapa, Allah sebagai Anak, dan Allah sebagai Roh Kudus. Ketiga pribadi ini merupakan satu kesatuan di dalam konsep "Allah Tritunggal”. Dalam lirik lagu kebangsaan ini digambarkan bahwa rakyat Afrika Selatan menganggap dirinya sebagai anak dari "Allah" yang mereka sembah. Rakyat percaya bahwa sosok 'Bapa' dapat dimohon bantuannya dan harus dihormati (Sunarko, $2017: 1$ ).

Aspek Penanda (Signifier)

Tuhan kami meminta Anda untuk melindungi bangsa kami.

\section{Aspek Petanda (Signified)}

Aksi mogok massak anti-Apartheid terjadi pada bulan Maret 1950 di Johannesburg. Aksi ini melibatkan aktivis dari pekerja kulit hitam Afrika, India dan kaum komunis. Selain itu perjuangan masyarakat lainnya juga terjadi di daerah 
pedesaan dan mencapai peningkatan kesadaran perlawanan baru. Di banyak daerah, ANC memimpin kampanye penghapusan tiket (pass) untuk perempuan, pendidikan, pemindahan paksa, kampanye pencabutan Undang-Undang Otoritas Baru. Hal yang menarik dari munculnya aksi-aksi protes menentang diterapkannya politik apartheid ini adalah munculnya persatuan gerakan rakyat yang semakin terorganisir, meluas dan modern metode perlawanannya. Aksi-aksi itu pun dipimpin oleh aktivis-aktivis pribumi yang tumbuh dari penindasan politik apartheid dan semakin matang dalam berpolitik seiring pengalamannya dalam lika-liku pergesekan (Paharizal, 2013:56).

\title{
Aspek Penanda (Signifier)
}

Campur tangan dan akhiri semua konflik.

\section{Aspek Petanda (Signified)}

Konflik yang dimaksud dalam lirik lagu ini adalah permasalahan yang terjadi akibat politik apartheid. Terjadi pemisahan ras antara golongan kulit putih dan golongan kulit hitam di Afrika Selatan. Agus Budiman dalam jurnalnya yang berjudul Politik Apartheid di Afrika Selatan menulis bahwa diskriminasi rasial merupakan salah satu masalah yang besar di awal abad ke-20 dan terdapat di beberapa negara seperti Amerika Serikat, Inggris dan yang paling dominan terdapat di Afrika Selatan dengan politik apartheid-nya. Oleh karena itu, Afrika Selatan menjadi fokus perjuangan anti rasialisme menuju realisasi keadilan. Politik apartheid dimulai saat Daniel F. Malan memimpin Uni Afrika Selatan pada tahun 1948. Namun sebenarnya pemisahan ras sudah dimulai saat masa pemerintahan Louis Botha sejak tahun 1910. Apartheid mengelompokkan tempat tinggal, pekerjaan, pendidikan, perkawinan, dan kekuasaan politik berdasarkan ras. Penduduk kulit putih memegang kekuasaan sedangkan penduduk kulit hitam tidak mendapatkan hak kehidupan yang layak (Budiman, 2013:17).

\section{Aspek Penanda (Signifier) \\ Lindungi kami, lindungi bangsa kami, Lindungi Afrika Selatan, Afrika Selatan. \\ Aspek Petanda (Signified)}

Penduduk Afrika Selatan kembali menyuarakan permohonannya kepada Tuhan untuk melindungi bangsanya. Hal ini disebabkan lagu ini awalnya merupakan lagu himne pemberontak Apartheid yang menginginkan pembebasan dan kesetaraan ras.bagi seluruh penduduk Afrika Selatan. Pada bagian ini tergambar kecintaan dan rasa patriotisme yang tinggi terhadap Afrika Selatan sehingga penduduk tidak ingin konflik pada masa Apartheid terus berlanjut atau timbulnya konflik lain di kemudian hari.

\author{
Aspek Penanda (Signifier) \\ Berdering dari surga biru kita, \\ Dari kedalaman lautan kita, \\ Di atas gunung yang abadi, \\ Dimana tebing gema bergema.
}

Aspek Petanda (Signified)

Bagian ini menggambarkan keindahan dan kekayaan alam yang dimiliki oleh Afrika Selatan. Surga biru menggambarkan pemandangan langit dan lautan yang indah. Kedalaman laut menggambarkan kondisi geografis Afrika Selatan yang terletak di antara Samudra Atlantik dan Samudra Hindia. Titik paling rendah adalah Samudra 
Atlantik pada $0 \mathrm{~m}$ dan paling tinggi ialah Gunung Njesuthi pada ketinggian $3.408 \mathrm{~m}$. Gunung tinggi yang dimiliki diharapkan abadi dan tebing yang bergema menandakan luas dan besarnya alam Afrika Selatan. Afrika Selatan memiliki banyak tebing dan menjadi daya tarik alam bagi para penduduk maupun turis seperti The Crags di Plettenberg Bay Pada bagian ini menggambarkan kebanggaan dan kekaguman penduduk Afrika Selatan terhadap bangsanya (https://www. saeon.ac.za/sadcofunstuff/OceansOfSA.htm diakses pada tanggal 25 Juni 2019 pukul 22.30 WIB).

\section{Aspek Penanda (Signifier)}

Terdengar panggilan untuk datang bersama dan bersatu kita akan berdiri. Aspek Petanda (Signified)

Desmond Tutu dalam buku Maisya Farhati yang berjudul The Traveling Students--Belajar dan Bertualang di Delapan Negara mengatakan bahwa masyarakat Afrika Selatan mempunyai satu filosofi atau semboyan yang disebut 'Ubuntu'. Ubuntu menekankan rasa saling membutuhkan atau interdependensi, kebersamaan, rasa saling memoliki dan empati antar sesama manusia. Secara singkat hal itu bisa dirumuskan dengan "I am because we are and we are because I am" Dari pernyataan tersebut dapat dirangkum bahwa pada lirik lagu kebangsaan ini mengandung filosofi Ubuntu di dalamnya. Pada bagian datang bersama dan bersatu menggambarkan masyarakat Afrika Selatan yang sangat berkemanusiaan dan menjunjung tinggi persatuan (Farhati, 2016:252).

\section{Aspek Penanda (Signifier)}

Mari kita hidup dan berjuang untuk kebebasan, di Afrika Selatan, tanah kami. Aspek Petanda (Signified)

Santoso A.Z. dalam bukunya yang berjudul Para Penggerak Revolusi mengatakan bahwa sebelum terjadi revolusi anti-Apartheid yang dipelopori Nelson Mandela, masyarakat Afrika Selatan merupakan sebuah masyarakat dengan tradisi segregasi atau pemisahan kelompok ras atau etnis secara paksa selama berpuluh-puluh tahun. Hal tersebut disebabkan ketidakpercayaan di antara berbagai kelompok terutama antara warga kulit putih dan kulit hitam. Oleh karena itu rekonsiliasi dan persatuan nasional menjadi prioritas utama gerakan yang dimotori Nelson Mandela (Santoso, 2017).

Inayet Hassan juga menambahkan bahwa pada saat ini mungkin generasi milenial tidak merasakan perjuangan berat yang dialami oleh pendahulu mereka. Tetapi lewat peristiwa sejarah yang menantang ini diharapkan dapat memberi pesan kepada masyarakat pada jaman ini untuk terus berjuang demi kesejahteraan seluruh penduduk Afrika Selatan (wawancara dengan Inayet Hassan di Kedutaan Besar Afrika Selatan, Jakarta pada tanggal 11 Juni 2019 pada pukul 15.10 WIB).

\section{Simpulan}

Penulis menyimpulkan beberapa kesimpulan yang menjadi hasil dari penelitian penulis sebagai berikut:

1. Nilai-nilai agama Kristiani sangat penting dan dijunjung tinggi oleh mayoritas masyarakat Afrika Selatan. Dapat dilihat dari prosentase warga yang beragama Kristen yaitu sekitar $80 \%$ dari total populasi Afrika Selatan. Konsep ketuhanan dipakai oleh mayoritas penduduk Afrika Selatan. 
2. Lagu Kebangsaan Afrika Selatan Nkosi Sikelel 'iAfrika menggambarkan penderitaan yang dialami rakyat khususnya yang berkulit hitam pada masa politik Apartheid. Lagu ini juga menceritakan bagaimana perjuangan masyarakat pada masa itu. Serta berisi ajakan untuk terus berjuang demi kebebasan di Afrika Selatan.

3. Di dalam Lagu Kebangsaan Afrika Selatan Nkosi Sikelel 'iAfrika terkandung filosofi Ubuntu. Ubuntu menggambarkan aspek kemanusiaan bagi masyarakat Afrika Selatan. Ubuntu menekankan rasa saling membutuhkan atau interdependensi, kebersamaan, rasa saling memoliki dan empati antar sesama manusia.

\section{Ucapan Terima Kasih}

Penulis mengucapakan rasa terima kasih yang sebesar-besarnya kepada seluruh pihak yang telah membantu dan mendukung penulis selama proses penelitian ini berlangsung sampai dengan terbitnya publikasi atas hasil penelitian ini.

\section{Daftar Pustaka}

A.Z, Santoso. (2017). Para Penggerak Revolusi. Jakarta: Laksana

Budiman, Agus.(2013). Politik Apartheid di Afrika Selatan. Jurnal Karya Tulis Dosen Unigal

Farhati, Maisya. (2016). The Traveling Students--Belajar dan Bertualang di Delapan Negara. Jakarta: Gramedia Pustaka Utama

Gilboa, Avi dan Ehud Bodner. (2009) What are your thoughts when the national anthem is playing? An empirical exploration. Psychology of Music Journal

Magangane, Ludumo. (2016). The National Anthem of South Africa. Johannesburg: Partridge Publishing Africa

Moleong, Lexy J. (2014). Metode Penelitian Kualitatif. Bandung: PT Remaja Rosdakarya

Paharizal. (2013). Long Walk Nelson Mandela. Yogyakarta: Narasi

Ridwan, H. Aang. (2016). Komunikasi Antarbudaya : Mengubah Persepsi dan Sikap dalam Meningkatkan Kreativitas Manusia. Bandung: CV Pustaka Setia

Sobur, Alex. (2013). Semiotika Komunikasi. Bandung: PT Remaja Rosdakarya

Soeratman, Darsiti. (2012). Sejarah Afrika. Yogyakarta: Ombak

Sujarweni, Wiratna. (2014). Metodologi Penelitian Lengkap, Praktis dan Mudah Dipahami. Yogyakarta: Pustakabarupress

Sunarko, Adrianus. (2017). Allah Tritunggal Adalah Kasih: Tinjauan HistorisSistematik. Bogor: Maharsa

Syah, Dedi Kurnia. (2016). Komunikasi Lintas Budaya : Memahami Teks Komunikasi, Media, Agama, dan Kebudayaan Indonesia. Bandung: Simbiosa Rekatama Media 